\title{
A case report of congenitally abnormal rabbit- headed stillbirth Najdi lamb
}

\author{
Mohamed M.M. Elsokary ${ }^{1 *}$, Seham, F. Shehata ${ }^{2}$ and Islam M. Saadedin ${ }^{3,4 *}$ \\ ${ }^{1}$ Department of Theriogenology, Faculty of Veterinary Medicine, Benha University, Benha 13511, Egypt \\ ${ }^{2}$ Department of Animal Wealth Development, Faculty of Veterinary Medicine, Benha University, Benha 13511, Egypt \\ ${ }^{3}$ Department of Animal Production, College of Food and Agriculture Science, King Saud University, Riyadh 11451, \\ Saudi Arabia \\ ${ }^{4}$ Department of Physiology, Faculty of Veterinary Medicine, Zagazig University, Zagazig 44519, Egypt
}

Received August 24, 2020

Revised September 7, 2020

Accepted September 8, 2020

\section{*Correspondence}

Mohamed M.M. Elsokary

E-mail: Mohamed.alsokary@fvtm.bu.edu.eg

ORCID

https://orcid.org/0000-0001-5595-0482

\author{
*Correspondence \\ Islam M. Saadedin \\ E-mail: isaadeldin@ksu.edu.sa
}

ORCID

https://orcid.org/0000-0002-7633-730X

\begin{abstract}
The congenital head anomalies are most often used to describe defects in the eyes, mouth, nose, skull, and or brain. The faulty embryogenesis most likely found to be associated with abnormal genetic or epigenetic causes during pregnancy. Eventually it leads to congenital anomalies. Rabbit-headed Lamb $(\mathrm{RH})$ is a disorder in sheep breeding that is characterized by some deformities in the head and the face. A dead -day old- crossbred white Najdi lamb with a deformed face and head was reported to be born in the current case. The external and physical examination revealed a deformed skull and facial region with a unilateral eye, fused mouth, piglike nose, and patent skull with the brain coming out from left eye orbit. Additionally, the lamb was very skinny with unusual long extremities. This is the first report of this syndrome that describes such deformities in a stillbirth Najdi breed lamb.
\end{abstract}

Keywords: congenital disorders, Najdi, sheep, stillbirth

\section{INTRODUCTION}

The Najdi is a type of breeds of domesticated sheep that inhabits natively the Najd region at mid region of the Arabian Peninsula. The Najdi breed is capable of living and surviving under stressful desert conditions (Alamer and Al-Hozab, 2004). Phenotypically, Najdi sheep has a fat tail, and a black-coat consists of long fleece. From the economic point of view, among all breeds, it comes first in the Arabian region for many reasons including but not limited to its high milk production and palatable taste even when its price as double as other breeds (Abouheif et al., 1989). Top Najdi ewes can sell for $\$ 5,300-8,000$ USD, while rams which can sire many more offspring can fetch up to 20,000 USD (The National, 2012). Congenital anomalies are imperfections of the regular anatomical features of neonates (Kwon et al., 2017; Jang et al., 2019). These abnormalities may cause dystocia problems and are mainly attributed, collectively or individually, to genetics, environmental predisposition, and or hormonal defects. These disorders take place during pregnancy, especially at the early stages of embryogenesis (Islam et al., 2011). Head congenital anomalies range from simple defects that interfere with normal physiological functions to a severe life-threatening issue (Rajabioun et al., 2016). Since this is a rare and unrecorded case in Najdi breeds, the aim of this report is to provide veterinarians and breeders with detailed descriptions and knowledge through the study of this case. 


\section{CLINICAL CASE}

A healthy 30 months old female Najdi ewe was presented to the teaching hospital of Faculty of Veterinary Medicine, Benha University, and showed the signs of approaching parturition. The ewe showed apparantely normal parturition with little traction. The male lamb was born alive with normal vital signs but very skinny with poor body condition. The lamb was lying down and unable to stand. Upon further examinations of the axial skeletal system, the lamb showed many head defects. From Left view (Fig. 1A) the head was looking very similar to rabbit head with long ears. When examined from the right craniolateral view (Fig. 1B) the lamb had a unilateral-right eye and absent orbital cavity of the left one. Additionally, the left cranio-lateral view of the lamb (Fig. 1C, D) showed patent and imperfectly closed skull with the brain coming out from the orbital cavity. Moreover, the facial bones of mandible and maxilla were absent with the oral and the nasal cavity of the lamb partially fused. The lamb had unusual long fore and hind limbs with no congenital abnormalities seen in the peripheral skeletal system on external examinations. After two hours, the lamb started to have hurried -shallow rapid- respiration, and eventually, the respiratory failure happened, and the lamb died.

\section{DISCUSSION}

This study described a congenital anomaly in a stillbirth
Najdi lamb. In neonates of small ruminants, clinical cases of malformations have been reported before (Diogo et al., 2019). However, in the present clinical case, the description and the location of the lesion, the faciocephalic area, are different from most reported cases. Additionally, congenital anomalies of limbs occur due to mutation in genes called HOX genes, which are essential components responsible for the interpretation of limb developmental patterns (Cohn and Bright, 1999). Among all mammals, sheep are the most affected animal (Mazzullo et al., 2003). In fact, because of the management and husbandry in most sheep farms, many affected animals are not detected (Dennis, 1993; Holmøy et al., 2012).

Many teratogenic agents were reported to induce congenital disorders, including long term exposure to poisonous plants, infectious diseases, pharmaceutical preparation, trace mineral imbalance, harmful radioactive materials, and heat stress factors (Dennis, 1993). These agents induce structural and genetic defects in gametes or in early developing embryos. Although adopting of cross-breeding strategies based on scientifically designed models can improve the genetics and productive traits of some sheep breeds, the incidence of hereditary disorders (Rahman et al., 2006) due to cross-breeding is occasionally seen in some breeds. When such cases take place, the breeders, stalk holders, and farm owners tend not to report to avoid the drastic economic losses and the adverse impact on the reputation of their breeds; thus, such cases are sporadically recognized (Scott, 2012). Some theories indicate that emerging of such cases is due to the sires or
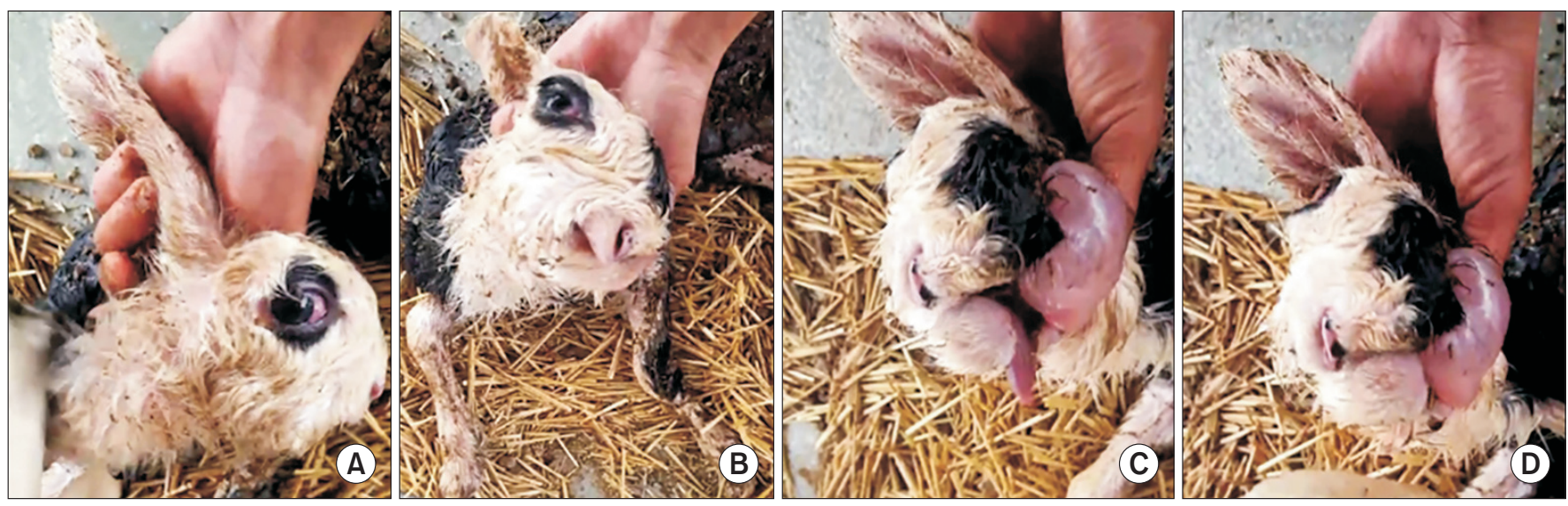

Fig. 1. The external description of the rabbit-headed Najdi lamb. (A) Right lateral view, showing a look similar to rabbit head with relatively long ear. (B) Right carniolateral view, showing absent oribital cavity of the left eye with pig-like mouth. (C, D) Left craniolaterla view, showing imperfect closure of the skull and protrusion of the brain out of eye site. 
dams that transmit autosomal recessive genes (Jolly et al., 2004). This mostly happens due to breeding between two sheep, one of which at least is not pure breed (Nazem et al., 2015). In this case, the genetic predisposition could not be generalized because it was the only case reported on the farm.

\section{CONCLUSION}

The current case study provides the first report of a rabbit-headed stillbirth lamb. Although the etiology of this case was not elucidated, this could be a model for further mechanistic and genetic studies for future similar cases.

\section{CONFLICTS OF INTEREST}

No potential conflict of interest relevant to this article was reported.

\section{AUTHOR CONTRIBUTIONS}

Conceptualization, M.M.M.E, and S.F.S; writing-original draft preparation, M.M.M.E, S.F.S, and I.M.S.; writingreview and editing, M.M.M.E, S.F.S, and I.M.S. All authors have read and agreed to the published version of the manuscript.

\section{AUTHOR'S POSITION AND ORCID NO.}

\author{
MMM Elsokary, Lecturer, \\ https://orcid.org/0000-0001-5595-0482 \\ SF Shehata, Lecturer, \\ https://orcid.org/0000-0001-9569-7522 \\ IM Saadeldin, Associate Professor, \\ https://orcid.org/0000-0002-7633-730X
}

\section{REFERENCES}

Abouheif MA, Abdo GM, Basmaeil SM, Alsobayel AA. 1989. Identification of the preference patterns of different breeds of sheep for consumption in Saudi Arabia. Asian-Australas. J.
Anim. Sci. 2:129-132.

Alamer M and Al-hozab A. 2004. Effect of water deprivation and season on feed intake, body weight and thermoregulation in Awassi and Najdi sheep breeds in Saudi Arabia. J. Arid Environ. 59:71-84.

Cohn MJ and Bright PE. 1999. Molecular control of vertebrate limb development, evolution and congenital malformations. Cell Tissue Res. 296:3-17.

Dennis SM. 1993. Congenital defects of sheep. Vet. Clin. North Am. Food Anim. Pract. 9:203-217.

Diogo R, Razmadze D, Siomava N, Douglas N, Fuentes JSM, Duerinckx A. 2019. Musculoskeletal study of cebocephalic and cyclopic lamb heads illuminates links between normal and abnormal development, evolution and human pathologies. Sci. Rep. 9:991.

Holmøy IH, Kielland C, Stubsjøen SM, Hektoen L, Waage S. 2012. Housing conditions and management practices associated with neonatal lamb mortality in sheep flocks in Norway. Prev. Vet. Med. 107:231-241.

Islam MR, Roh YS, Cho A, Park H, Heo SY, Lee K, Lee HK, Lim CW, Kim B. 2011. Multiple congenital anomalies in a Korean native calf (Bos taurus coreanae). Korean J. Vet. Res. 51:5559.

Jang SJ, Kim M, Lee HJ, You YS, Lee J, Lee SL. 2019. Newborn English bulldogs with multiple malformation syndrome and lethal characters. J. Anim. Reprod. Biotechnol. 34:253-258.

Jolly RD, Blair HT, Johnstone AC. 2004. Genetic disorders of sheep in New Zealand: a review and perspective. N. Z. Vet. J. 52:52-64.

Kwon K, Lee B, Choi S, Cho J, Lee Y, Choi H. 2017. Diagnostic imaging of congenital meningoencephalocele in a Holstein calf. J. Emb. Trans. 32:33-38.

Mazzullo G, Germanà A, De Vico G, Germanà G. 2003. Diprosopiasis in a lamb. A case report. Anat. Histol. Embryol. 32:6062.

Nazem MN, Shojaei B, Asadi A, Hasanzadeh M. 2015. A case presentation of spider lamb syndrome in a Kermanian breed lamb. Vet. Res. Forum 6:343-347.

Rahman MM, Khan MS, Biswas D, Sutradhar BC, Saifuddin AK. 2006. Pygomelia or supernumerary limbs in a crossbred calf. J. Vet. Sci. 7:303-305.

Rajabioun M, Kazemi Mehrjerdi H, Ghasemi S. 2016. A case report of partial bilateral hind limb adactyly in a male lamb. Vet. Res. Forum 7:357-359.

Scott P. 2012. Some common genetic defects in sheep. UK Vet. Livest. 17:42-45.

The National. Prized sheep sold for Dh75,000 at auction. Accessed June 29, 2020. 